\title{
UWARUNKOWANIA I MOŻLIWE KONSEKWENCJE POLITYCZNE WPROWADZENIA PODATKU TOBINA LUB PODATKU SPAHNA
}

\author{
DETERMINANTS AND POSSIBLE POLITICAL CONSEQUENCES \\ OF IMPLEMENTATION OF TOBIN TAX OR SPAHN TAX
}

\author{
Arkadiusz Fordoński* 우
}

\begin{abstract}
ABSTRAKT
W tekście omówiono założenia oraz podstawowe uwarunkowania wdrożenia dwóch wersji podatku od transakcji walutowych: podatku Tobina oraz podatku Spahna. Celem artykułu jest wskazanie i analiza uwarunkowań politycznych, które mogą być istotne dla wprowadzenia każdej z tych koncepcji, a także możliwych konsekwencji wprowadzenia jednego z tych mechanizmów. Problem badawczy brzmi: na ile możliwe polityczne konsekwencje wprowadzenia podatku Tobina oraz podatku Spahna mogą zaważyć na podjęciu decyzji o wdrożeniu któregoś z nich. Można w tym kontekście postawić hipotezę, że spodziewane konsekwencje polityczne wprowadzenia każdego z tych rozwiązań stanowią podstawowy i trudny do przezwyciężenia problem w drodze do ich implementacji. Weryfikacja tej hipotezy będzie miała znaczenie dla oceny działań ruchów społecznych i partii politycznych, zmierzających do realizacji projektów przebudowy globalnego systemu ekonomicznego czy też reformy Unii
\end{abstract}

The following text discusses the idea and main determinants of the implementation of the concepts of Tobin tax and Spahn tax. The aim of this paper is to analyze and show political determinants which could be important for the implementation of Tobin tax or Spahn tax and to analyze their possible consequences. The article deals with the following research problem: to what extent the possible political consequences of the implementation of Tobin tax or Spahn tax are important to make a decision regarding its implementation? The article aims at verifying the following hypothesis: the expected political consequences are the basic obstacle for the implementation of Tobin tax or Spahn tax and this obstacle will be difficult to overcome. The verification of this hypothesis is important for the evaluation of the activities of social movements and political parties which raise the question of the reform of global economic system or the European Union by implementation of one of

* Mazowiecka Uczelnia Publiczna w Płocku, Wydział Nauk Humanistycznych i Społecznych. 
Europejskiej przez wprowadzenie jednego z tych podatków i odpowiednie zagospodarowanie pozyskanych środków.

Słowa kluczowe: podatek Tobina; podatek Spahna; podatek od transakcji walutowych; podatek od transakcji finansowych; stabilizacja; polityka fiskalna these taxes and appropriate management of the funds raised in this way.

Keywords: Tobin tax, Spahn tax; currency transaction tax; financial transaction tax; stabilization; fiscal policy

\section{WSTĘP}

Podatek Tobina nie jest ideą w pełni prekursorską, a wątpliwości budzi też stwierdzenie, że jest najbardziej optymalnym spośród rozwiązań mających stabilizować globalne rynki finansowe, ale pomimo to właśnie on stał się symbolem dążenia do powściągnięcia nadmiernej spekulacji dotykającej waluty. W warunkach globalizacji, w sytuacji, w której środki finansowe o wartości wielokrotnie przekraczającej wartość PKB gospodarki światowej bez przeszkód przenoszą się pomiędzy granicami w ramach transakcji, których uczestnicy liczą przede wszystkim na uzyskanie natychmiastowych zysków, władze nawet najpotężniejszych państw mogą okazać się bezsilne wobec zjawisk rynkowych powodujących gwałtowną aprecjację lub deprecjację ich walut. Jedną z propozycji, która miała odpowiedzieć na niedostatki koncepcji Tobina, jest tzw. podatek Spahna. Obie, jak pokażę, są nie tylko koncepcjami ekonomicznymi, ale także niosą ze sobą istotne konsekwencje polityczne. Świadomość tych konsekwencji może oddziaływać na decydentów politycznych i powodować niechęć wobec tych inicjatyw.

Niestabilność rynków kapitałowych jest elementem debat ogniskujących zainteresowanie ekonomistów, specjalistów w dziedzinie finansów publicznych, aktywistów społecznych i polityków. Wśród nich coraz częściej dyskutuje się więc wprowadzenie efektywnych mechanizmów opodatkowania transakcji finansowych, które nie tylko przynosiłyby określone rezultaty fiskalne, ale także takich, które mogłyby stabilizować rynki finansowe. Oba rozważane podatki sytuują się w szerszym nurcie, $w$ ramach którego dyskutowane jest wprowadzenie podatku od transakcji walutowych (currency transaction tax - CTT), a także rozwiązania obejmującego zarówno handel walutami, jak i różnego rodzaju instrumentami finansowymi, a zatem podatku od transakcji finansowych (financial transaction $\operatorname{tax}-\mathrm{FTT})$. 
Poszczególne wersje FTT i CTT różnią się w części swoich założeń, zróżnicowana jest także hierarchia celów, jakim mają służyć - w szczególności odmiennie ocenia się rolę jego funkcji stabilizacyjnej i fiskalnej. W zależności od kontekstu politycznego podatki tego rodzaju mogą być wdrażane $\mathrm{w}$ formach mniej lub bardziej odbiegających od ich koncepcji. Kontekst polityczny ma również podstawowe znaczenia dla decyzji, czy podatek w ogóle zostanie wprowadzony. Artykuł ma na celu wskazanie uwarunkowań politycznych, które mogą mieć wpływ na wprowadzenie każdej z tych koncepcji, a także możliwych konsekwencji wprowadzenia jednego z powyższych mechanizmów. W związku z tym problem badawczy brzmi: na ile możliwe polityczne konsekwencje wprowadzenia podatku Tobina oraz podatku Spahna mogą zaważyć na podjęciu decyzji o wdrożeniu któregoś $\mathrm{z}$ nich. W badaniu skupiono się na realiach państw Unii Europejskiej. Wstępnie przyjęto hipotezę, że możliwe konsekwencje polityczne wprowadzenia każdego z tych podatków mogą mieć istotne znaczenie już dla decyzji o jego wdrożeniu.

\section{PRZESZKODY WE WPROWADZENIU PODATKU TOBINA}

Propozycja Jamesa Tobina dotyczyła kluczowego elementu systemu finansowego. To stabilność walut decyduje o warunkach wymiany handlowej czy bezpieczeństwie inwestycji zagranicznych. Jej zachwianie ma skutki nie jak w przypadku kursu akcji na życie tysięcy inwestorów, lecz na całe narody, szczególnie w krajach rozwijających się (Kapoor, 2009, s. 9-10). Mając na uwadze, że zachwianie kursu dużego przedsiębiorstwa w gospodarce będącej systemem naczyń połączonych dotyka także jego kontrahentów, a w mniejszej lub większej skali całego rynku, wpływ ten nie jest z pewnością tak bezpośredni. To właśnie doniosłość problemu sprawiła, że propozycja Tobina spotkała się z takim zainteresowaniem - późniejszy noblista zaproponował, jak w prosty sposób ograniczyć skalę problemu, którego znaczenie miało z czasem jeszcze wzrosnąć.

Koncepcja podatku mającego stabilizować rynki finansowe poprzez ograniczenie płynności na rynku wywodzi się z myśli ekonomicznej Johna Maynarda Keynesa. W swej pracy Ogólna teoria zatrudnienia, procentu i pieniądza wskazywał, że na giełdzie nowojorskiej i londyńskiej kapitał spekulacyjny odgrywa odmienną rolę. Z powodu niższych kosztów transakcji w Nowym Jorku znacznie łatwiej niż w Londynie mogli inwestować przeciętni obywatele. Brytyjczycy musieli ponosić wyższe koszty obsługi maklerów, a transakcje obciążał 
odpowiednio wysoki podatek. W rezultacie rola spekulantów była w Stanach Zjednoczonych większa. W opinii Keynesa wprowadzenie podatku w „znacznej” wysokości w USA sprawiłoby, że transakcje spekulacyjne stałyby się mniej opłacalne, a przez to ich rola spadłaby (Keynes, 2003, s. 140-141).

James Tobin, formułując postulat wprowadzenia podatku od transakcji walutowych, wychodził od racji ekonomicznych, które z pewnością moglibyśmy też wpisać w kontekst bezpieczeństwa ekonomicznego. Kluczowe było dla niego zagwarantowanie, że państwa będą miały autonomię w kształtowaniu swojej polityki monetarnej, przez co o jej konkretnym obliczu będzie decydował interes gospodarczy każdego z nich (Tobin, 1974, s. 88). W ten sposób koncepcja odpowiada na jeden z problemów dotykających bezpieczeństwa finansowego, będącego elementem bezpieczeństwa ekonomicznego. $\mathrm{W}$ nieco późniejszym tekście Tobin precyzował, że spekulacja na rynkach walutowych wpływa na poziom krajowych stóp procentowych, w efekcie czego polityka fiskalna i walutowa prowadzona przez rządy oraz banki centralne w mniejszym stopniu odpowiada potrzebom gospodarek narodowych. Rezultaty niestabilności kursów walutowych są bardzo istotne - oddziałuje ona na inflację, wydajność gospodarek i poziom bezrobocia (Tobin, 1978, s. 154). Wyjściem w obliczu tego problemu nie jest przyjęcie płynnego czy też stałego kursu waluty ${ }^{1}$, pożądane rezultaty może natomiast spowodować zarówno wprowadzenie prognozowanego przez niego podatku, jak i rozwijanie procesów integracji gospodarczej państw, w tym wprowadzenie wspólnej waluty i budowanie wspólnej polityki monetarnej (co dziś ma już miejsce w UE) oraz realizacja projektów wspólnej polityki fiskalnej. Tobin uważał jednak w tym czasie, że tego rodzaju obiecujące projekty w przewidywalnej perspektywie czasowej, przez którą rozumiał XX wiek, są nierealistyczne (Tobin, 1978, s. 154-155).W jego ocenie zatem proponowany podatek był nie tyle jedynym wyjściem z sytuacji, co raczej rozwiązaniem właściwym, a jednocześnie możliwym do zrealizowania. Uzasadniając jego użyteczność, zwracał uwagę, że obecna sytuacja na rynkach walutowych powoduje konieczność koordynacji polityk walutowych państw, które prowadzą ze sobą znaczną wymianę handlową, co jest bardzo trudne. Podnosił także, że interwencje na rynkach, które

1 Po upadku systemu z Bretton Woods wiązał z systemem kursów płynnych nadzieje (Tobin, 1974, s. 88-89), jednak następnie dostrzegł, że instrument z tym mechanizmem związany, a więc możliwość obniżania stóp procentowych i zwiększanie podaży pieniądza, ma w istocie ograniczone znaczenie - powoduje wzrost kursów innych walut, co w połączeniu ze spekulacją walutową może skutkować znacznym wzrostem inflacji. Rezultatem tego rodzaju polityki jest też trudność w pozyskaniu kapitału na rynkach międzynarodowych (Tobin, 1978, s. 156-157). 
mają przecież na celu stabilizację, same powodują niestabilność (Tobin, 1978, s. 157-158; Gajda-Kantorowska, 2014, s. 191-192).

Pomimo że Tobin nie stronił od popierania rozwiązań interwencjonistycznych i fiskalistycznych (Tobin, 1974, s. 6-17), to jego inicjatywa była motywowana troską o zapewnienie rozwoju warunków swobodnej wymiany handlowej - dowodził, że jego mechanizm nie ma ograniczać handlu dobrami i usługami, lecz transakcje pozorujące handel (Tobin, 1978, s. 159²).

Wychodząc $\mathrm{z}$ tych przesłanek, Tobin proponował, by podatkiem objąć transakcje kasowe wymiany walut. Początkowo niewiele uwagi przywiązywał do poziomu stawki - proponował, by wynosiła ona $1 \%$, ale wskazywał na tę stawkę, używając sformułowania "powiedzmy” (say). Zmierzał do tego, by przyjęta stawka podatku była na tyle znaczna, by czyniła znacznie mniej zyskownymi transakcje spekulacyjne i na tyle niewysoka, aby nie oddziaływała w ten sam sposób na handel międzynarodowy (Tobin, 1974, s. 89).

Podatek Tobina miał być wprowadzony w zunifikowanej formule w skali międzynarodowej. Ekonomista nie przewidywał zróżnicowania stawek podatku, kategorii podmiotów zwolnionych od niego, ani nie ustalał zasad przyznawania ulg i umorzeń. Znaczenia nie miała mieć waluta, w jakiej przeprowadzano by transakcje, zatem gdyby w Londynie dokonywano wymiany walut bez udziału funta - np. euro na jeny - podatek i tak egzekwowałby rząd brytyjski. Każde z państw, które zgodziłoby się na jego wprowadzenie, mogłoby samodzielnie nim administrować. Wpływy mogłyby być wpłacane do Banku Światowego lub Międzynarodowego Funduszu Walutowego ${ }^{3}$. Tobin szybko dostrzegł ryzyko obchodzenia proponowanego przez niego podatku powodowane przez objęcie nim jedynie transakcji wymiany waluty za walutę, stąd też zaproponował, aby objąć nim również transakcje przy użyciu instrumentów finansowych denominowanych w różnych walutach. Zauważał, że mimo tego mogą pojawić się rozwiązania pozwalające na obchodzenie podatku, jednak, jak oceniał, będą one generować pewne koszty, a zatem nie udaremnią w pełni celu podatku, jakim jest uczynienie transakcji spekulacyjnych mniej rentownymi (Tobin, 1978, s. 159).

2 Podobną argumentację odnajdujemy także u innych amerykańskich progresywistów, którzy wskazują, że aktywność państwa jest konieczna, ale po to, by właściwie funkcjonował rynek (Stiglitz, 2015, 142-144).

3 Tobin podaje początkowo skrót IME, a następnie IMF, ale wydaje się, że jest to niedostrzeżony w korekcie błąd i cały czas chodzi mu o Międzynarodowy Fundusz Walutowy (Tobin, 1978, s. 158 $-159)$. 
Tobin nie chciał tworzyć jakiejkolwiek bariery dla handlu, jednak miał świadomość, że jego podatek będzie go w pewnej mierze utrudniał, uważał jednak, że trudności z nim związane będą mniejsze niż niedogodności, jakie generuje trwanie systemu wymiany walut $\mathrm{w}$ niezmienionej postaci. Przewidywał też mechanizm, który miał ułatwiać handel w ramach regionów - wskazywał, że za zgodą Międzynarodowego Funduszu Walutowego państwa mogłyby tworzyć obszary walutowe, na terenie których podatek nie obowiązywałby w odniesieniu do transakcji wymiany walut zrzeszonych w ten sposób państw. W rezultacie na przykład w ramach EWG, czy dziś UE, podatek nie utrudniałby działań mających na celu ściślejszą integrację gospodarek narodowych (Tobin, 1978, s. 159).

Propozycja wprowadzenia nowego podatku była dla Tobina działaniem nakierowanym na stabilizację rynku walutowego oraz zwiększenie możliwości państw w sferze polityki gospodarczej. Z uwagi na skalę transakcji dokonywanych współcześnie na rynkach walutowych wprowadzenie takiego podatku, nawet przy stawce znacznie niższej niż początkowo proponował jego pomysłodawca, mogłoby przynieść niebagatelne wpływy do budżetów państw, które by go wprowadziły lub organizacji międzynarodowych, które miałyby być beneficjentami jego wprowadzenia. W przeszłości próbowano oszacować te wpływy. O ile przyjęte metody szacunkowe były trafne, to należy zauważyć, że środki, jakie można by pozyskać z wprowadzenia w przyszłości podatku, byłyby większe z powodu rozwoju rynku finansowego. Głośnym opracowaniem odwołującym się do idei Tobina jest przygotowany przez Organizację Narodów Zjednoczonych w 1994 r. Human Development Report, w którym wskazywano, że podatek przy stawce $0,05 \%$ zastosowany w skali globalnej powinien przynieść 150 mld USD rocznie w latach 1995-2000 (United Nations, 1994, s. 9). W 1997 r. znany działacz alterglobalistyczny i popularyzator idei Tobina Ignacio Ramonet twierdził, że przy stawce $0,1 \%$ wprowadzenie podatku Tobina przyniesie 166 mld dolarów rocznie. Wskazywał jednocześnie, że jest to kwota na tyle znacząca, że dwuletni dochód z tego podatku wystarczyłby na zwalczenie skrajnego ubóstwa do końca XX wieku (Ramonet, 1997) ${ }^{4}$. Nowsze szacunki, pochodzące z 2011 r., oparte na bardziej aktualnych danych dotyczących obrotów na międzynarodowych rynkach walutowych, odnajdujemy w opracowaniu Global Policy Forum. Autorzy

${ }^{4}$ Jego tekst i późniejsza działalność dały asumpt do powstania międzynarodowego ruchu społecznego znanego przede wszystkim pod skrótową nazwą ATTAC - Association pour la Taxation des Transactions pour l' Aide aux Citoyens, który z czasem rozszerzał pole swoich postulatów o inne, mające w przekonaniu jego działaczy stanowić alternatywę wobec aktualnego kształtu globalizacji. 
przyjęli, że skoro dzienne obroty na światowych rynkach finansowych wynoszą 4 bln dolarów, to wprowadzenie podatku na poziomie od $0,005 \%$ do $0,25 \%$ (stosunek stawek 1:50) przyniosłoby roczne przychody w skali globalnej w wysokości od 15 do 300 mld dolarów (stosunek szacowanych przychodów 1:20). Autorzy szacunku nie podali przyjętej metody (Global Policy Forum, 2011). Otrzymane wartości wskazują jednak, że przyjęto przy tym wzór zakładający odpowiedź rynku, której efektem byłoby zmniejszenie liczby transakcji w sytuacji, gdyby zdecydowano się na wyższą stawkę podatku - uwzględniono zatem hipotetyczny przebieg krzywej Laffera. Dostrzegając możliwość zmniejszenia obrotów przy wyższej stawce, David Hillman, Sony Kapoor i Stephan Spratt twierdzą, że stawka podatku na poziomie połowy punktu bazowego, a więc $0,005 \%$, nie powinna spowodować zmian na rynku, a jednocześnie przyniosłaby znaczny dochód. Autorzy ci podają wartości przychodów, jakie w ten sposób udałoby się pozyskać dla kilku rynków, a mianowicie: dla rynku euro - 4,55 mld dolarów, rynku funta brytyjskiego -2,08 mld dolarów i dla korony norweskiej - $170 \mathrm{mln}$ dolarów (Hillman, Kapoor, Spratt, 2006, s. 24-25). Jeżeli jednak przyjęte przez nich założenie jest słuszne, to w takim wypadku przy stawce $0,005 \%$ podatek nie odniósłby skutku przewidzianego przez Tobina, ponieważ nie zmniejszyłby skali transakcji spekulacyjnych na rynkach walutowych.

Znaczne rezultaty fiskalne mogą być traktowane przez rządzących jako istotna szansa na poprawienie sytuacji budżetowej ich państw. Jednak fakt, iż propagatorzy koncepcji wskazują, że pieniądze uzyskane w ten sposób należy powierzyć organizacji międzynarodowej i przeznaczyć na cele ważne z perspektywy całego globu, takie jak walka z ubóstwem czy ociepleniem klimatu, może rzutować negatywnie na tego rodzaju nadzieje. Do wprowadzenia podatku mogą też zniechęcać inne powody. Negowane jest już podstawowe założenie Tobina, iż wprowadzenie podatku od transakcji walutowych wpływałoby stabilizująco na rynki. Na nieskuteczność podatku w tym zakresie wskazują wyniki części dotychczas prowadzonych badań empirycznych na temat przeprowadzonych prób wprowadzenia podatku Tobina lub inspirowanych nim podatków w poszczególnych krajach. Małgorzata Gajda Kantorowska wskazuje, że pojawiały się przez to następujące problemy: wbrew przewidywaniom zwiększają się wahania cen, zmniejsza się płynność rynku i przejrzystość cen, zmniejszają, a nie zwiększają się wpływy podatkowe (Gajda-Kantorowska, 2014, s. 198-200). Najczęściej podnoszonym zagrożeniem ekonomicznym jest jednak ryzyko odpływu kapitału z państwa, które zdecydowałoby się na jego wprowadzenie. Potwierdzeniem wiarygodności tego rodzaju obaw jest przykład Szwecji, która jako pierwsza podjęła 
się wprowadzenia rozwiązania opartego na propozycji Tobina i już po kilku latach musiała się z tej inicjatywy wycofać, ponieważ skutkiem było przeniesienie się wielu inwestorów do Norwegii i Wielkiej Brytanii. Mając na względzie to zagrożenie, można próbować wprowadzać podatek od transakcji walutowych o stawce na tyle niskiej, aby nie powodował negatywnych reakcji rynku, ale po pierwsze ograniczy to jego skuteczność w stabilizowaniu rynku, a po drugie przy dzisiejszych możliwościach przenoszenia kapitału może to być niezwykle trudne. Aby podatek mógł stabilizować rynek i nie powodować trudności związanych z odpływem inwestorów, musiałby zostać wprowadzony w skali globalnej, a to, jak wszystkie podobne inicjatywy, wydaje się nierealne. Pomimo zarysowanych problemów koncepcję Tobina w różnej formie próbowało wdrożyć szereg państw, w tym m.in. Francja czy Węgry. Komisja Europejska w 2011 r. w toku prac nad budżetem na lata 2014-2020 zaproponowała wprowadzenie unijnego podatku od transakcji finansowych. Inicjatywie zdecydowanie sprzeciwiała się jednak część państw, co stało się powodem jej fiaska. W związku z tym 11 państw członkowskich zdecydowało się na wprowadzenie podatku w ramach procedury wzmocnionej współpracy w oparciu o decyzję Rady z 22 stycznia 2013 r. (Wniosek...; Decyzja...) $)^{5}$. Wśród państw objętych mechanizmem znalazły się: Austria, Belgia, Estonia, Francja, Grecja, Hiszpania, Niemcy, Portugalia, Słowacja, Słowenia, Włochy (Gajda-Kantorowska, 2014, s. 191-200; Kawecka-Wyrzykowska, 2014, s. 61-95).

$\mathrm{Na}$ wprowadzeniu podatku mogą stracić państwa o najsilniejszych rynkach finansowych. Obecnie obrót walutami koncentruje się w większej części zaledwie w kilku państwach (Schulmeister, Schratzenstaller-Altzinger, Picek, 2008, s. 3; Kapoor, 2004, s. 13-14). Działające tam instytucje finansowe byłyby najważniejszymi płatnikami podatku - kapitał, jakim dysponują, daje im znaczne wpływy w sferach rządzących i może je odwodzić od tego posunięcia. Jego wprowadzeniu może nie sprzyjać przede wszystkim kolejny aspekt jego konsekwencji fiskalnych - problematyczna jest kwestia podziału środków z wprowadzenia podatku, a ich wielkość może tylko wzmacniać opór tych, którzy uznają to rozwiązanie za krzywdzące $\mathrm{z}$ ich perspektywy. Jeśli miałyby zasilić jedną z organizacji międzynarodowych, to skala tych środków spowodowałaby znaczący wzrost jej

5 Propozycji wprowadzenia unijnego FTT zdecydowanie sprzeciwiały się w tym czasie: Cypr, Wielka Brytania, Luksemburg i Bułgaria, a zatem co do zasady państwa czerpiące znaczące zyski ze względu na umiejscowienie na ich terytorium instytucji finansowych. Decyzji w proponowanej formie nie popierało jednak wiele więcej państw (Patrz szerzej: Gajda-Kantorowska, 2014, s. 194). 
znaczenia, co oczywiście może wywoływać obawy zarówno rządzących państwami, dla których dalsza kooperacja $\mathrm{z}$ tak potężną organizacją stanowiłaby znaczne wyzwanie, jak społeczeństw poszczególnych państw, które mogłyby się obawiać, że w ten sposób nadmierny wpływ na politykę międzynarodową zacznie wywierać podmiot niemający demokratycznej legitymacji. Co więcej, pojawiałby się także dylemat wyboru celu, na który miałyby być przeznaczane owe środki, co wiąże się z wyborem organizacji. Jest oczywiście szereg problemów, które mają pewne znaczenie dla całej ludzkości, ale, jak pokazuje kwestia trudności $\mathrm{w}$ wypracowaniu porozumienia dotyczącego przeciwdziałania zmianom klimatycznym, percepcja tego rodzaju problemów jest w poszczególnych państwach zróżnicowana. Gdyby natomiast wybrać najprostsze, jak się zdaje rozwiązanie, i pozyskane pieniądze miałyby zasilać budżety państw, w których dokonuje się transakcji, to z pewnością pojawiłby się opór państw o słabszych rynkach finansowych, które nie bez racji mogłyby wskazywać, że wbrew rozpowszechnionym postulatom podatek puryfikowałby różnice ekonomiczne między państwami.

\section{PODATEK SPAHNA}

Twórcą tzw. podatku Spahna jest Paul Bernd Spahn, specjalista w dziedzinie finansów publicznych, emerytowany profesor na Uniwersytecie Goethego we Frankfurcie nad Menem. Głośna propozycja amerykańskiego noblisty stała się dla tego niemieckiego badacza punktem wyjścia do sformułowania bardziej wyrafinowanej koncepcji, dwupoziomowego podatku od transakcji walutowych (two-tier CTT). Spahn był zdania, że koncepcja Tobina jest wartościowa, ale wskazywał na jej dwie zasadnicze słabości: nieskuteczność w zwalczaniu ataków spekulacyjnych i możliwość zmniejszenia płynności na rynku. W związku z tym jego podstawowym założeniem stało się zróżnicowanie obciążenia transakcji w zależności od tego, czy mogą destabilizująco wpływać na kurs waluty.

Spahn zwracał uwagę, że podatek proponowany przez Tobina był propozycją w znacznym zakresie niedookreśloną. Dla realizacji tej idei konieczne byłoby wypracowanie części istotnych elementów: określenie podstawy opodatkowania, zidentyfikowanie transakcji mających być opodatkowanymi, określenie stawki podatku i mechanizmu podziału dochodów podatkowych. Tobin proponował rozwiązanie, które mogło w określonej wersji zadziałać, a w innej okazać się nawet destrukcyjne. Spahn natomiast, korzystając ze swojej wiedzy w zakresie finansów publicznych, postarał się o wykorzystanie go dla zarysowania podstawowych 
problemów związanych z wyborem odpowiedniego kształtu poszczególnych elementów konstrukcji podatku. Dowodził, że dla stabilizacji rynków finansowych ważne jest, by nie było kategorii transakcji wyłączonych $\mathrm{z}$ opodatkowania i by opodatkowana była cała wartość transakcji. Z drugiej strony dostrzegał jednak, że są całe kategorie transakcji, których celem nie jest spekulacja, a zatem są racje dla ich wyłączenia spod opodatkowania. Znakomitym przykładem są tu oczywiście transakcje banków centralnych dokonywane w okresach interwencji na rynku, ale można także wskazać na transakcje market makerów, którzy dzięki nim utrzymują płynność na rynku. Jak dalej przyznawał, transakcje rynkowe co do zasady sprzyjają płynności, a tylko niektóre z nich mają cel spekulacyjny. W związku z tym wskazywał na potrzebę zbudowania takiej konstrukcji daniny, która z jednej strony będzie prosta, a z drugiej na tyle selektywna, że nie będzie ograniczać płynności na rynku. Niewłaściwe było według niego proponowane przez Tobina opodatkowanie jedynie transakcji kasowych - trafnie zauważył, że taki mechanizm można łatwo obchodzić dzięki wykorzystaniu instrumentów pochodnych, a to również będzie powodować zmiany na rynku walutowym. Zwracał ponadto uwagę na istotny dylemat: opodatkowanie jedynie kwoty zainwestowanej w zakup waluty może prowadzić do tego, że wartość ta będzie zaniżana, co można uzyskać dzięki większemu lewarowaniu transakcji, z kolei uczynienie podstawą opodatkowania wartości nominalnej transakcji może spowodować poważne problemy na rynku derywatów. Opodatkowanie derywatów niższą stawką również nie jest według niego rozwiązaniem pozbawionym słabości - problemem będzie wybór stawki dla tych transakcji, który w opinii badacza może być nie tylko arbitralny, ale nawet stronniczy. Wprowadzenie elementu zróżnicowania stawek spowoduje oczywiście także większe skomplikowanie podatku (Spahn, 1996, s. 24-25).

Według Spahna założenie Tobina, że podatek powinien być pobierany od każdej transakcji niezależnie od tego, czy dochodzi do zmiany kursu, jest niewłaściwe. Według niego wysokość podatku powinna być w jakimś stopniu związana ze skalą zmiany kursu waluty, a w związku z tym z dochodem, jaki mógł osiągnąć podmiot dokonujący transakcji. Stawka powinna zbliżać się do zera, jeżeli nie zachodziłyby zmiany kursu. W przypadkach znacznych zmian powinna być natomiast odpowiednio wysoka. Jak słusznie zauważał, nawet relatywnie wysoka stawka podatku na poziomie $1 \%$ skutecznie nie odstraszy inwestorów liczących, że dzięki spekulacji osiągną zysk sięgający 3\% wartości transakcji. Problem stawki jest złożony jeszcze z jednego względu - z uwagi na spodziewany efekt fiskalny. Według Spahna wysoka stawka, która przecież 
może lepiej oddziaływać stabilizująco, spowoduje spadek obrotów na rynku, a przez to nie uda się osiągnąć wpływów, które będą odpowiadały odsetkowi ich wartości. Zatem statyczna ocena, że skoro w owym czasie dzienna wartość wszystkich transakcji na rynku derywatów i transakcji kasowych na świecie sięgała 1,23 bln USD, to dzięki wprowadzeniu podatku o stawce w wysokości $1 \%$ otrzymamy 12,3 mld dziennie i ok. 3250 mld rocznie, nie jest realistyczna. Jak się zresztą wydaje, taki podatek spowodowałby załamanie koniunktury. Spahn oceniał, że zupełnie inna byłaby odpowiedź na podatek na poziomie dwóch punktów bazowych, a więc $0,02 \%$. Według niego reakcja byłaby wtedy bardzo umiarkowana, a statyczny szacunek wpływów stawałby się bliskim ich realnej wartości - w tym czasie można byłoby więc zapewne liczyć na kwotę około 64 mld USD. W przypadku tak znacznych środków istotną kwestią staje się zagadnienie ich podziału. Niemiecki badacz zgadzał się zasadniczo na tym polu z Tobinem, że beneficjentami wpływów mogą być państwa, państwa za pośrednictwem organizacji międzynarodowej lub organizacje międzynarodowe. Pierwsze rozwiązanie wydaje się stosunkowo proste, jednak pojawia się w tym przypadku zagadnienie harmonizacji stawek, a także wspomniany już problem puryfikowania różnic ekonomicznych pomiędzy państwami, ponieważ gdyby dzielić je ze względu na miejsce dokonania transakcji, to najwięcej zyskałoby zaledwie kilka państw o najsilniejszych rynkach kapitałowych. Problem utrwalania nierówności gospodarczych pojawi się również przy przyjęciu innego rozważanego rozwiązania, a więc podziału proporcjonalnie do wielkości środków wniesionych do MFW, wówczas także zyskaliby głównie najbogatsi. Ten problem nie pojawiłby się, gdyby podatek przeznaczyć na określony cel dotykający całej ludzkości - choćby ochronę zdrowia lub środowiska naturalnego; jednak jak już wskazałem, osiągnięcie zgody co do takiego celu może być niezwykle trudne (Spahn, 1996, s. 25).

Wychodząc od podstawowego punktu swej diagnozy dotyczącej podatku Tobina, a więc stwierdzenia, że podatek ten w sytuacji, gdyby wybrano za wysoką stawkę, ograniczy handel (także ten, co do którego pozytywnego znaczenia dla światowej gospodarki nie ma wątpliwości), a jeśli będzie za niski, to w efekcie nie wpłynie w pożądany sposób na spekulację, Spahn proponował zróżnicowanie stawek i - co kluczowe - dostosowanie ich do zagrożenia, któremu miał przeciwdziałać. W okresie, gdy stabilność waluty danego państwa nie byłaby zagrożona, Spahn wskazywał, że stawka powinna być na tyle niska, by nie wpływać negatywnie na skalę wymiany walut - jak oceniał, taki rezultat można będzie osiągnąć przy stawce $0,02 \%$ dla transakcji kasowych i $0,01 \%$ dla transakcji na 
derywatach. W ten sposób udałoby się uniknąć także sytuacji, w której regulacja byłaby obchodzona przez stosowanie derywatów. W sytuacjach, gdyby wahania kursu waluty przekraczały granice wyznaczonego dla danej waluty pasma wahań, do podstawowej stawki podatku dla ograniczenia handlu doliczano by znaczącą dopłatę (surcharge). Według Spahna byłoby to „opodatkowanie negatywnych skutków związanych z nadmierną zmiennością" (Spahn, 1996, s. 26). Dzięki zróżnicowaniu znacznie mniej rentowne stawałyby się transakcje zawierane w okresie ataków spekulacyjnych, przez to i same ataki spekulacyjne mogłyby okazywać się nieopłacalnymi - instrument ten miał mieć więc potencjał, by skuteczniej niż interwencje banków centralnych stabilizować kursy walut (Spahn, 1996 s. 24; Buckley, Aren, 2011, s. 241; Hybka, 2013, s. 62; Kapoor, s. 15). Warto zauważyć, że wyższa stawka mogłaby obejmować jedynie transakcje gotówkowe, a jej rozciągnięcie na instrumenty pochodne mogłoby zajść dopiero, gdyby wystąpiła taka potrzeba, co jednak, jak sądzę, rodzi niebezpieczeństwo, że odpowiedni mechanizm mógłby w kluczowym momencie nie zadziałać.

Oczywiście pewna selektywność rozwiązania ograniczającego spekulację jest pożądana, pojawia się jednak pytanie o kluczowy w takiej sytuacji mechanizm pozwalający na wyznaczanie pasma wahań, w którym obowiązywałaby jedynie niższa stawka. Spahn sądził, że odpowiedni byłby dla tego celu „kurs pełzający”, oparty np. o średnią ruchomą, do którego dodawany byłby określony procent docelowej stawki. Nie bez racji pomysłodawca porównywał go więc do europejskiego mechanizmu kursów walutowych. Metoda powinna być uniwersalna dla wszystkich rynków i walut, natomiast ustalony margines mógłby być dla poszczególnych walut zróżnicowany. Jest to rozwiązanie trafne, gdyż różnice w zmienności kursów poszczególnych walut są znaczne. Spahn dostrzegał także rolę okresu indeksowania - im byłby krótszy, tym większe wahania byłyby dopuszczalne. Badacz wskazywał, że powinien być wystarczająco krótki, by pozwolić uczestnikom rynku dostosować się do zmian fundamentalnych. W tej sytuacji podatek na wyższym poziomie byłby pobierany stosunkowo rzadko jedynie w okresach, gdy wahania kursu okazywałyby się zbyt destabilizująco wpływać na sytuację danej waluty. Spahn uważał, że podatek powinien objąć cały świat, jednak ten cel według niego można będzie zrealizować stopniowo mogłoby go początkowo wprowadzić także jedno lub kilka państw. Dowodził, że jego inicjatywa będzie nieść wiele pozytywnych konsekwencji. Pozwoliłaby według niego nie tylko zapobiegać kryzysom walutowym i pozyskać dodatkowe środki na cele publiczne, ale także stabilizować kursy walut w dłuższej perspektywie, chronić państwa przed przeznaczaniem znacznych rezerw na potrzeby 
stabilizacji walut i przed podejmowaniem ryzykowanych działań mających na celu korektę kursu walutowego, wreszcie upodmiotowiłaby w większym stopniu rządy i banki centralne na polu polityki gospodarczej. Propozycja miałaby także poprawiać alokację środków w światowej gospodarce i ograniczać obecną wśród inwestorów pokusę nadużycia (Spahn, 1996, s. 26-27)6.

Jak oceniam, podatek Spahna jest nie tylko bardziej skonkretyzowaną niż podatek Tobina wersją podatku od transakcji walutowych. Innowacyjna konstrukcja dwupoziomowa istotnie rodzi szanse, że podatek okaże się selektywnym narzędziem, które w przeciwieństwie do pierwotnej koncepcji nie spowoduje znaczących zakłóceń na światowych rynkach finansowych. Jednak jego najistotniejsza strona, a więc pewna selektywność, dlatego że jest jedynie „względną" selektywnością, może również rodzić pewne zagrożenia. Przez to, że powoduje, iż handel walutą poza wyznaczonym pasmem wahań staje się nieopłacalny, utrudnia nie tylko ataki spekulacyjne, ale także wycofanie się inwestorów mających inne niż czysto spekulacyjne cele z gospodarek, co do których zaufanie w określonych warunkach znacznie spadło. Uzasadniona przecież chęć redukcji strat, których przyczyna może chociażby tkwić np. w nieodpowiedzialnych działaniach rządu danego państwa, może w tych okolicznościach zderzać się z istotną barierą w postaci podatku, który jeszcze by owe straty potęgował. Świadomość, że może wystąpić taka sytuacja, mogłaby sprawić, że pozyskanie kapitału przez kraje rozwijające się będzie jeszcze trudniejsze - inwestorzy, bojąc się, że będą narażeni na poważne straty, mogą tym mniej chętnie inwestować w państwach, co do których stabilności nie będą w pełni przekonani.

Jestem zdania, że w porównaniu z propozycją Tobina podatek Spahna może być mniej destrukcyjny dla handlu międzynarodowego, a jednocześnie skuteczniejszy w przeciwdziałaniu atakom spekulacyjnym. $Z$ jego realizacją wiąże się jednak ten sam co w przypadku podatku Tobina problem, a zatem zagadnienie modelu podziału ewentualnie pozyskanych środków. O ile dokładne szacunki dotyczące tego zagadnienia są obarczone znacznym ryzykiem błędu, to pewne jest, że będzie chodziło o kwoty znaczne nawet $\mathrm{z}$ perspektywy dużych państw, w zależności od przyjętej stawki sięgające w skali globalnej kilkudziesięciu, a może nawet setek miliardów dolarów. W konsekwencji i w tym wypadku rozbieżność interesów poszczególnych państw i grup może być na tyle poważna, że podatek nigdy nie zostanie wprowadzony w zunifikowanej formie w skali globalnej, a jego wprowadzenie w skali regionu może być niezwykle trudne -

\footnotetext{
${ }^{6}$ Na temat pokusy nadużycia patrz: Iwanicz-Drozdowska, 2009, s. 32-33.
} 
tym samym jego znaczenie stabilizacyjne może być trudne do zweryfikowania w praktyce.

Koncepcja Spahna spotkała się ze znacznym zainteresowaniem, w tym ze zdecydowaną krytyką. Warto zauważyć, że na łamach wpływowego pisma „Finance and Development” w numerze, w którym autor ten przedstawił jej założenia, polemikę opublikowała Janete W. Stotsky. Autorka przypomniała, że podatki o zmiennej stawce są rzadko stosowane, ponieważ powodują niepewność cen. Zastosowanie podatku, który przyczyni się do wzrostu niepewności, może spowodować efekty, które właśnie z uwagi na niepewność mogą ograniczyć jego pozytywne owoce i doprowadzić do wzrostu spreadów. Tego rodzaju podatki są też skomplikowane zarówno dla podatników, jak i administracji podatkowej - według autorki wynikające z tej niepożądanej właściwości problemy mogą być bardzo widoczne właśnie w przypadku tej propozycji, a to dlatego, że liczba objętych mechanizmem transakcji byłaby „tak ogromna” (so huge). Stotsky podnosiła wątpliwości co do zasadności łączenia polityki monetarnej (monetary policy) i podatkowej (tax policy), gdyż ta pierwsza szybciej się zmienia i jest co do zasady niepodatna na wpływy polityczne, druga zmienia się rzadziej, ale jest podporządkowana celom politycznym ${ }^{7}$. Dodawała, że wprowadzenie podatku wymagałoby współpracy w dziedzinie fiskalnej i monetarnej, której obecnie nie ma. Wskazywała, że choć dotąd nie wprowadzono podatku Tobina, to badania empiryczne innych rozwiązań nie dają silnych dowodów potwierdzających, że wzrost cen transakcji powoduje ograniczenie zmienności na rynku. Autorka wskazała, że dane historyczne pokazują, że choć w przeszłości koszty transakcji były wyższe, to ich spadek nie spowodował wzrostu zmienności (Stotsky, 1996, s. 28). Co interesujące, autorka przywoływała też badania wskazujące, że trudno ocenić motywacje różnych uczestników rynku i na tej podstawie wysnuwała wniosek, że trudno też wyróżnić destabilizujące transakcje, a w konsekwencji to je obłożyć podatkiem - racje dla restrykcyjnego opodatkowania wszystkich transakcji krótkoterminowych są natomiast według niej nieprzekonujące. Wydaje się jednak, że w tym miejscu jej krytyka była nieadekwatna, ponieważ główną racją uzasadniającą wyższe opodatkowanie transakcji krótkoterminowych jest

\footnotetext{
7 Według Josepha Stiglitza niezależność banków centralnych, które odpowiadają za prowadzenie polityki monetarnej w praktyce oznacza brak demokratycznej kontroli, gdy tymczasem ich decyzje są z gruntu polityczne. Wskazuje przy tym, że postulowana niezależność nie wyklucza wpływów sektora finansowego i podaje przykłady sytuacji, w których owocowało to podporządkowaniem działań deklaratywnie niezależnej instytucji interesom sektora finansowego (Stiglitz, 2013, s. $408-413)$.
} 
nie tyle motywacja zdestabilizowania sytuacji - choć ta oczywiście może występować - lecz destabilizujące rezultaty. Nie chodzi wszak o to, by podmioty tak postępujące ukarać, ale o to, by kształtować ich zachowania i w ten sposób modelować sytuację na rynku. Stotsky zwracała też uwagę na negatywne konsekwencje wprowadzenia podatku dla płynności instrumentów pochodnych, służących zabezpieczeniu uczestników rynku przed skutkami nadmiernych wahań kursów walut. Odnosząc się do twierdzeń Spahna dotyczących potrzeby skonstruowania na tyle selektywnego rozwiązania, by nie obejmowało działania trade makerów i instytucji finansowych - banków centralnych, zaznaczała, że podmioty te nie muszą oddziaływać stabilizująco na rynek, a z drugiej strony, wyłączenia mogą powodować sytuacje, w których opodatkowane podmioty będą wykorzystywać te nieopodatkowane dla swych transakcji. Stotsky podnosi ponadto, że nawet niska stawka podatku w normalnych warunkach handlu międzynarodowego, zważywszy na jego realia, a więc niskie stopy zwrotu kapitału, może okazać się istotna - zatem według autorki nawet podatek, którego stawka, jak proponuje Spahn, będzie wynosić 0,02\%, może negatywnie wpłynąć na handel międzynarodowy, szczególnie że podatek ten, obciążając poszczególne transakcje na tych samych dobrach lub usługach, może owocować wielokrotnie wyższą niż podstawowa stawką dla odbiorcy. Ponadto w jej ocenie nieadekwatne jest ustalenie stawki podatku dla instrumentów pochodnych w wysokości połowy stawki dla instrumentu bazowego, z powodu złożoności strategii wykorzystywanych w obrocie derywatami. Stotsky dostrzegała też problemy związane z łatwością unikania opodatkowania podatkiem od transakcji walutowych poprzez przenoszenie transakcji do państw, w których ono nie obowiązuje. Co pokazał czas, słusznie ocenia, że kompromis wokół wprowadzenia takiego rozwiązania może być trudny do osiągnięcia nie tylko w skali globalnej, ale nawet regionalnej, np. w ramach UE (Stotsky, 1996, s. 29).

Koncepcja Spahna stała się podstawą inicjatywy legislacyjnej w Belgii, której owocem było uchwalenie w 2004 r. ustawy, na mocy której w państwie tym ma być wprowadzony podatek od transakcji walutowych, jednak pod warunkiem, że rozwiązanie to wdrożą także pozostałe państwa należące do unii gospodarczej i walutowej (Economic and Monetary Union). Podstawową stawkę podatku ustalono na poziomie $0,02 \%$, ale także, idąc za propozycją Spahna, przewidziano mechanizm dopłaty, który miał być stosowany w przypadku znaczących wahań kursowych, ale którego dokładna stawka miała być uzależniona od decyzji organu UE, a więc Rady do Spraw Gospodarczych i Finansowych (Economic and Financial Affairs Council). 


\section{ZAKOŃCZENIE}

Idea opodatkowania sektora finansowego wzbudziła bardzo duże zainteresowanie społeczne w wielu państwach wskutek kryzysu na amerykańskim rynku nieruchomości. Podatek od transakcji finansowych, spopularyzowany jako "podatek Robin Hooda", stał się jednak w znacznej mierze synonimem mechanizmu redystrybucji od ,jednego procenta” najzamożniejszych do reszty społeczeństwa, czy też instrumentem, za sprawą którego sektor finansowy poniesie odpowiedzialność za wywołane załamanie koniunktury, a nie rozwiązania mającego stabilizować rynki. Promowany przez działaczy społecznych kojarzonych z lewicą, organizację Adbusters, a także wpływowych ekonomistów, takich jak: Joseph Stiglitz, Paul Krugman, Dani Rodrik czy Jeffrey Sachs, uzyskał wsparcie nie tylko przywódców politycznych socjaldemokracji, ale także stojących na czele ugrupowań chrześcijańsko-demokratycznych czy konserwatywnych (jak choćby Angela Merkel czy Nicholas Sarkozy). Dla porozumienia w UE lub G20 wokół idei kluczowe było jednak nie tyle zainteresowanie rozwiązaniem polityków bardziej sceptycznych wobec rozwiązań socjalnych, co raczej uzyskanie aprobaty państw, które czerpią największe dochody z funkcjonowania na ich terytorium instytucji finansowych.

Propozycja Tobina odnosiła się początkowo do transakcji kasowych - Spahn swoją koncepcję formułował już w innych realiach gospodarczych i w związku z tym od początku przewidywał także opodatkowanie instrumentów pochodnych. Dziś to drugie wydaje się być nieodzowne, o ile wprowadzenie podatku ma wywrzeć doniosłe skutki na rynkach kapitałowych. Stephan Schulmeister, Margit Schratzenstaller-Altzinger i Oliver Picek, podjęli się oceny efektów fiskalnych wprowadzenia podatku od transakcji finansowych w kilku wybranych państwach europejskich (Austrii, Niemczech, Szwajcarii oraz Wielkiej Brytanii), a także przeanalizowali go w odniesieniu do gospodarki światowej oraz najistotniejszych jej regionów. Podkreślają oni, że kluczową rolę miałoby w tym kontekście właśnie opodatkowanie derywatów. W Niemczech inne typy transakcji nie zapewniłyby w ich ocenie efektu fiskalnego nawet na poziomie $0,1 \%$ PKB, przy stawce na poziomie $0,1 \%$ podstawy opodatkowania, jednak

8 „Podatek Robin Hooda” to zasadniczo podatek od transakcji finansowych, choć pod tą nazwą można odnaleźć także propozycje, w których przedmiot opodatkowania jest inny - cechą go wyróżniającą jest w pierwszym rzędzie cel, jakim jest wyrównywanie różnic w poziomie zamożności i realizacja celów o zasięgu globalnym, jak walka z ubóstwem, AIDS czy zmianami klimatu. 
opodatkowanie derywatów na tym samym poziomie powinno przynieść około piętnastokrotnie większy przychód. Autorzy ci założyli ponadto, że obniżenie stawki opodatkowania o określoną wartość nie zaowocuje proporcjonalnym spadkiem wpływów. W ich ocenie, gdyby w Niemczech podatek miał dziesięciokrotnie niższą niż uprzednio rozważana stawkę, a zatem $0,01 \%$, wpływy spadłyby o 2/3. U źródeł takiej zależności należy upatrywać wpływu, jaki na transakcje z wykorzystaniem derywatów wywierałby podatek - stawka na poziomie $0,1 \%$ mogłaby znacząco zmniejszyć wartość transakcji (Schulmeister i in., 2008, s. 2-3). Ci sami autorzy zwracają uwagę, że $99 \%$ transakcji na derywatach w UE jest dokonywanych właśnie w Niemczech oraz Wielkiej Brytanii, a w tej sytuacji wprowadzenie podatku w tych dwóch krajach mogłoby mieć kluczowe znaczenie dla sytuacji w całej Wspólnocie. Nawet te dwa państwa może jednak dotknąć zjawisko odpływu kapitału w sytuacji, gdyby koszty transakcji zwiększyły się względem tych w innych krajach UE9. Szczególnie obecnie, w sytuacji niepewności związanej z wystąpieniem Wielkiej Brytanii z tej organizacji, wprowadzenie zharmonizowanego podatku od transakcji finansowych w realnej perspektywie w całej UE wydaje się nieprawdopodobne. Rządy pozostałych we Wspólnocie państw mogłyby w takiej sytuacji zaprzepaścić jedną z najpoważniejszych szans związanych z co do zasady niekorzystnym dla nich rozbratem ze Zjednoczonym Królestwem, gdyż zniechęciłyby inwestorów, którzy dziś mogą szukać nowego miejsca, w którym mogliby zawierać swoje transakcje.

Podatek od transakcji walutowych lub - szerzej - podatek od transakcji finansowych jest rozwiązaniem, które budzi pewne nadzieje na ustabilizowanie rynków finansowych i pozyskanie istotnych środków na długofalowe działania społeczne i ekologiczne, ale z którym wiąże się też ryzyko odpływu kapitału, a w konsekwencji spowolnienia gospodarczego i wzrostu bezrobocia. Zagrożenia i wyzwania z nim związane nie przekreślają tej idei, a szanse, że z czasem zostanie wprowadzony jako mechanizm obowiązujący w całej Unii Europejskiej, są dość znaczne. O tym, że zostanie wdrożony, pozwala sądzić znaczne zainteresowanie społeczeństw Wspólnoty i wysokie poparcie dla inicjatywy. Jak wskazują badania Eurobarometru z 2010 r., pomysł wprowadzenia podatku od transakcji

${ }^{9}$ Wspomniani badacze uznają, że z uwagi na rolę tych dwóch rynków w europejskim systemie finansowym oraz nieznaczny wpływ opodatkowania transakcji na poziomie $0,05 \%$ bądź $0,01 \%$ na transakcje zawierane poza rynkiem derywatów problem ten nie dotknie ich. Tamże, s. 3. Na rynku derywatów, gdzie marża kształtuje się często na poziomie od 0,01 do 0,05\%, taka stawka miałaby oczywiście zupełnie inne znaczenie - przyjęcie stawki na poziomie 0,01 czyniłoby część transakcji nieopłacalnymi. Patrz: S. Kapoor, dz. cyt., s. 14. 
finansowych cieszył się co prawda znacznie mniejszym poparciem niż wprowadzenie przez UE bardziej restrykcyjnych regulacji przeciwdziałających unikaniu opodatkowania czy działalności „rajów podatkowych”, ale i tak opowiadało się za nim $61 \%$ Europejczyków. Sprzeciw wyrażało 25\% respondentów, a 14\% nie miało w tej sprawie zdania (European Commission, 2011a). Badanie w $2011 \mathrm{r}$. przyniosło niemal takie same rezultaty, $61 \%$ respondentów było za (w tym $30 \%$ zdecydowanie, a 31 wyrażało umiarkowane poparcie), 26\% było przeciw (11 zdecydowanie, a 15\% deklarowało, że są dość przeciwni) - zdania nie miało 13\% (European Commission, 2011b). W ostatnich latach pomysł jest nieco rzadziej dyskutowany, ale powraca szczególnie w kontekście debat o finansowaniu procesu zacieśniania integracji europejskiej.

BibLIOGRAFIA:

Buckely, R.P., Aren, D.W. (2011). From Crisis to Crisis. The Global Financial System and Regulatory Failure. Alphen aan den Rijn: Kluwer Law International.

European Commision. (2011a). Crisis and food security. Pobrane z: http://www.europarl.europa.eu/pdf/eurobarometre/2011/juin/22062011/eb_75_2_\%20report\%20 financial_\%20crisis\%20iii\%20_en.pdf.

European Commision. (2011b). Economic governance in the European Union. Pobrane z: https://ec.europa.eu/commfrontoffice/publicopinion/archives/eb/eb74/ eb74_en.pdf.

Decyzja Rady z dnia 22 stycznia 2013 roku upoważniająca do podjęcia wzmocnionej współpracy w dziedzinie podatku od transakcji finansowych (2013/52/UE).

Gajda-Kantorowska, M. (2014). Podatek Tobina - kontrowersje teoretyczne i uwarunkowania praktyczne. Studia i Materiaty. Miscellanea Oeconomicae, 1, 191-200.

Global Policy Forum. (2011). Curency Transaction Taxes. Pobrane z: https://www. globalpolicy.org/social-and-economic-policy/global-taxes-1-79/currency-transaction-taxes.html.

Hillman, D., Kapoor, S., Spratt, S. (2007). Taking the next step. Implementing a currency transaction development levy. Pobrane $\mathrm{z}$ : https://www.globalpolicy.org/images/pdfs/ 12ctdl.pdf.

Hybka, M.M. (2013). Podatek od transakcji finansowych - dyskusyjny instrument przeciwdziałania spekulacjom rynkowym. Zeszyty Naukowe Uniwersytetu Szczecińskiego, 766, 59-68.

Iwanicz-Drozdowska, M. (2009). Pokusa nadużycia a kryzys subprime. Zeszyty Naukowe Uniwersytetu Szczecińskiego, 548, 32-37.

Kapoor, S. (2004). The currency transaction tax enhancing financial stability and financing development. Pobrane z: file:///C:/Users/HP/Downloads/The_Currency_Transaction_Tax.pdf. 
Kawecka-Wyrzykowska, E. (2014). Propozycje zmian systemu finansowania UE: wnioski dla Polski. Ekonomia, 39, 61-85.

Keynes, J.M. (2003). Ogólna teoria zatrudnienia, procentu i pieniądza. Warszawa: Wydawnictwo Naukowe PWN.

Ramonet, I. (1997). Disarming the markets. Pobrane z: http://kit.mondediplo.com/spip. php?article2469.

Schulmeister, S., Schratzenstaller-Altzinger, M., Picek, O. (2008). A General Transaction Tax - Motives, Revenues, Feasibility and Effects. Wien: WIFO Studies.

Spahn, P.B. (1996). Tobin Tax and Exchange Rate Stability. Finance and Development, 33(2), 24-27.

Stiglitz, J.E. (2013). Cena nierówności. Warszawa: Wydawnictwo Krytyki Politycznej.

Stotsky, J.G. (1996). Why a Two Tier Tobin Tax Won't Work. Finance and Development, 33(2), 28-29.

Tobin, J. (1978). A proposal of international monetary reform. Eastern Economic Journal, 4 (3-4), 153-159.

Tobin, J. (1974). The new economics one decade older. Princeton: Princeton University Press.

Quaghebeur, M. (2004). Belgium Supports Tobin Tax. Pobrane z: http://www.taxation. be/pdf/t039.pdf, 727-729.

United Nations. (1994). Human Development Report 1994. New York-Oxford: Oxford University Press.

Wniosek. Dyrektywa Rady w sprawie wspólnego systemu podatku od transakcji finansowych i zmieniająca dyrektywę 2008/7/WE, KOM 2011 594, Bruksela 10.10.2011. 